\title{
MENJALIN KEBERSAMAAN DALAM MENUJU KESUKSESAN, BERJIWA BESAR, DAN OPTIMIS UNTUK MENJADI WIRAUSAHA BARU (BATIK NYERE)
}

\author{
Ae Suaesih ${ }^{1}$, Sumeidi kadarisman ${ }^{2}$, Bambang Susanto $^{3}$, R. Aryanti Ratnawati ${ }^{4}$, \\ Eva Rachmawati ${ }^{5}$, Rusmin Nuryadin ${ }^{6}$ \\ ${ }^{1,5,6}$ Progran Studi Keuangan dan Perbankan, Fakultas Ekonomi, Universitas Sangga Buana \\ ${ }_{2,3,4}$ Progran Studi Manajemen, Fakultas Ekonomi, Universitas Sangga Buana
}

${ }^{1}$ korespondensi : ae.suaesih@usbypkp.ac.id

\begin{abstract}
ABSTRAK
Meningkatkan motivasi para UMKM dengan mengidentifikasi dan memberikan solusi terhadap faktor-faktor yang menghambat para UMKM untuk berwirausaha. Motivasi pada individu dapat timbul karena adanya kebutuhan yang mendorong untuk melakukan pekerjaan. Individu akan memiliki dorongan untuk melakukan pekerjaan wirausaha dikarenakan adanya keyakinan kuat bahwa profesi wirausaha merupakan jalan terbaik untuk melakukan perubahan kualitas kehidupan secara individual maupun bermasyarakat. Sebelum memperoleh keyakinan diri tersebut, calon wirausahawan ini telah melakukan berbagai pertimbangan dan pemikiran tentang beragam aspek yang di butuhkan untuk berwirausaha. Berdasarkan hasil wawancara dengan para UMKM di bidang batik tepatnya batik nyere didapatkan bahwa $75 \%$ para umkm yang masih kurang termotivasi tentang kewirausahaan dan keterampilan untuk berwirausaha. Sebagai solusi untuk permasalahan tersebut, maka tim pengabdi memberikan Motivasi kewirausahaan para umkm khusunya di bidang batik. Hasil evaluasi, maka diperoleh hasil dan manfaat dari kegiatan pengabdian ini diantaranya adalah meningkatnya motivasi kewirausahaan dan faktor faktor yang mempengaruhinya.
\end{abstract}

Kata Kunci : Motivasi, Kewirausahaan

\section{ABSTRACT}

Increase the motivation of umkm by identifying and providing solutions to the factors that hinder umkm from becoming entrepreneurs. Motivation in individuals can arise because of a need that encourages doing work. Individuals will have the urge to do entrepreneurial work due to the strong belief that the entrepreneurial profession is the best way to change the quality of life individually and in society. Before gaining this selfconfidence, this aspiring entrepreneur has made various considerations and thoughts about the various aspects needed for entrepreneurship. Based on the results of interviews with umkm in the field of batik, to be exact, batik nyere, it was found that $75 \%$ of umkm were still less motivated about entrepreneurship and skills to be entrepreneurial. As a solution to these problems, the service team provides entrepreneurial motivation for umkm, especially in the field of batik. The results of the evaluation show that the results and benefits of this service activity include the increase in entrepreneurial motivation and the factors that influence it.

Keyword: Motivation, Entrepreneurship

\section{PENDAHULUAN}

Jawa Barat terkenal dengan pengrajin batik diantaranya seperti daerah Cirebon, Jawa Tengah, dan D.I Yogyakarta, sehingga Nilai ekspor batik dan produk batik sampai dengan semester I tahun 2017 mencapai USD39,4 juta dengan tujuan pasar utamanya ke Jepang, Amerika Serikat (AS), dan Eropa. Capaian ini menandai bahwa industri batik nasional memiliki daya saing yang komparatif dan kompetitif di pasar internasional. Indonesia telah menjadi market leader yang menguasai pasar batik dunia. Makanya, batik yang menjadi identitas bangsa kita, semakin populer dan mendunia. Potensi pasar ekspor batik nusantara masih bisa ditingkatkan, mengingat perdagangan produk pakaian jadi dunia sebesar USD442 miliar [1]. Selain itu, pengakuan 
internasional tersebut juga telah membangkitkan semangat para perajin dan industri batik nasional untuk terus mengembangkan usahanya, sehingga dapat meningkatkan kesejahteraan masyarakat. Namun meski nilai ekspor sudah cukup tinggi, berdasarkan fakta dilapangan tidak semua hasil ekspor dinikmati oleh para pengrajin batik nyere, dikarenakan kebanyakan penjualan terhambat Sumber Daya Manusia dan Modal.

Pengusaha batik nyere yang sudah ada selama ini hanya berfokus pada pelatihan-pelatihan untuk mentransfer ilmu atau keahlian dalam proses pembuatan batik nyere tersebut [2]. Berdasarkan pemantauan dilapangan, diantaranya sudah ada 800 orang yang tercatat sebagai peserta pelatihan yang telah dibina. Hal ini pula yang diketemukan oleh tim pengabdian masyarakat ketika melakukan survey pendahuluan pada pengrajin batik nyere. Masalah yang di rasakan oleh batik nyere yaitu terkait produksi, modal dan pemasaran. Masalah lainnya adalah kebanyakan produk batik nyere hanya di produksi apabila menunggu suatu permintaan konsumen dan masih bersifat kelompok. Usaha batik nyere yang sudah ada tentunya perlu terus didorong agar mampu terus tumbuh dan berkembang dengan mencoba mencarikan solusi atas permasalahan yang dihadapinya, yang diantaranya dalam permodalan, produksi dan pemasaran. Oleh karena itu dalam upaya membantu memecahkan masalah yang dihadapi sehingga kemampuan para perajin batik dalam pengelolaan usahanya dapat teroptimalkan dengan beroperasi secara lebih efektif dan efesien sehingga lebih mampu bersaing dengan produk sejenis baik didalam maupun untuk tujuan ekspor, maka tim pengabdian masyarakat berencana mengadakan kegiatan Pengabdian Pada Masyarakat dilingkungan perajin batik nyere di Kecamatan Cicendo, Bandung.

Pengabdian pada Masyarakat yang akan melibatkan pelaku usaha UMKM ini, dalam perencanaan dan pelaksanaan programnya akan melibatkan mitra dengan memperhatikan kearifan lokal, potensi masyarakat wilayah tersebut dan kemampuan tim PPM pada program pengabdian masyarakat secara umum dalam rangka transfer ilmu untuk peningkatan wawasan pengetahuan, keterampilan masyarakat yang diharapkan memiliki manfaat ekonomis dan pemberdayaan para perajin batik.

\section{METODE}

Metode kegiatan dalam rangka pengabdian pada masyarakat secara umum berbentuk workshop yang terdiri dari program. Workshop yang dilaksanakan adalah workshop mengenai motivasi bagi pembatik nyere. Motivasi dapat diartikan sebagai keadaan kejiwaan dan sikap mental manusia yang memberikan energi, mendorong kegiatan (moves) dan mengarah atau menyalurkan perilaku ke arah mencapai kebutuhan yang memberi kepuasan atau mengurangi ketidakseimbangan [3]. Dengan adanya motivasi, seseorang bisa terdorong untuk melakukan sesuatu yang lebih baiik lagi. Beberapa program workshop yang diberikan adalah sebagai berikut: 
1. Memberikan motivasi untuk fokus menjadi wirausaha dan lebih produktif.

2. Memupuk kretifitas dan kerjasama, materi ini bermaksud agar setiap kelompok pengrajin batik nyere bisa bekerja sama dalam menyelesaikan batik nyere.

3. Memupuk sikap mental di era globalisasi mental yang kuat sangat di butuhkan bagi semua pengusaha karena persaingan yang begitu ketat.

4. Pengurus juga dapat membantu untuk dapat memahami "kebutuhan" manusia

5. Memotivasi untuk menjadi seorang pemimpin,bagaimana dan kapan harus melakukan

6. Setiap pengusaha apalagi pengusaha yang baru tidak boleh takut akan kegagalan.

\section{HASIL DAN PEMBAHASAN}

Pelaksanaan kegiatan pengabdian pada masyarakat bertempat di Kecamatan Cicendo jl. Purabaya No.1 Bandung. Secara rinci hasil kegiatan sebagai berikut:

1. Materi 1 tentang motivasi kewirausahaan Sesuai hasil kesepakatan dengan pendiri batik nyere, maka workshop memberikan pengetahuan tentang motivasi menjadi seorang pengusaha untuk membangun semangat para pengrajin batik nyere. Materi disampaikan oleh beberapa dosen Fakultas Ekonomi dengan materi antara lain:

- Memberikan motivasi untuk fokus menjadi wirausaha

- Memupuk kretifitas dan kerjasama, materi ini bermaksud agar setiap kelompok pengrajin batik nyeri bisa bekerja sama dalam menyelesaikan batik nyere

- Memupuk sikap mental maju, dalam era globalisasi mental yang kuat sangat di butuhkan bagi semua pengusaha karena persaingan yang begitu ketat.

- Memotivasi untuk menjadi seorang pemimpin

- Tidak takut gagal dan tidak takut menyerah, setiap pengusaha apalagi pengusaha yang baru tidak boleh takut akan kegagalan.

- keinginan akan kesejahteraan fisiologis dan material

- Keinginan untuk memuaskan hubungan antar personal

- Keinginan akan perkembangan dan pertumbuhan psikologis berkelanjutan.

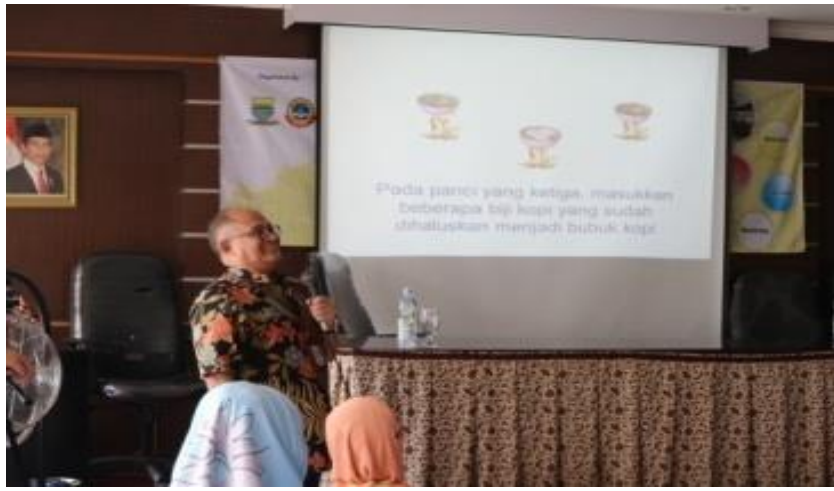

Gambar 1: Pemaparan Materi PKM tentag Motivasi oleh Pemateri (Sumeidi Kadarisman,SE.,MSi)

Jurnal Pengabdian kepada Masyarakat USB, Volume 1 No 2 bulan November tahun 2020 
Hasil dsikusi/Tanya jawab memperlihatkan adanya kendala yang dihadapi para pengrajin batik nyere ini terkait motivasi antara lain:

a. Belum terjalin kerjasama yang kuat dalam membangun batik nyere.

b. Belum memilik Mental untuk memulai wirausaha.

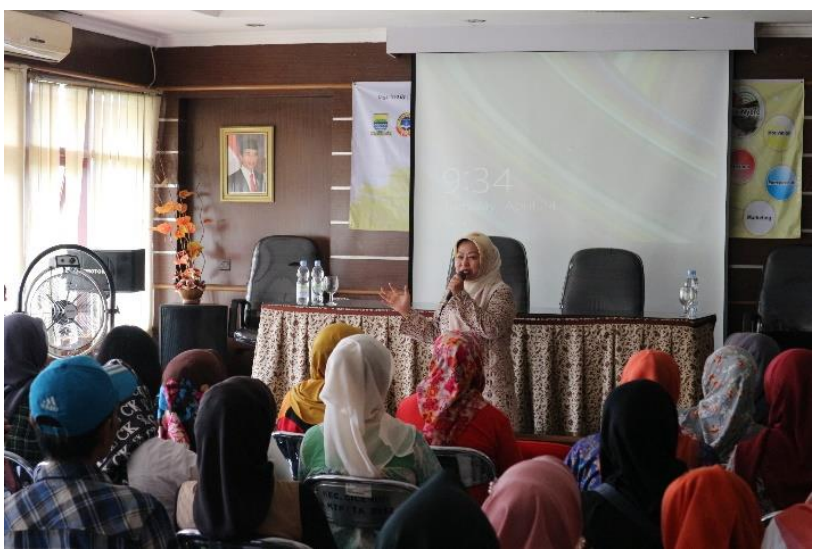

Gambar 2: Pemaparan Materi PKM tentag Motivasi oleh Pemateri (Ae Suaesih,SE.,MSi)

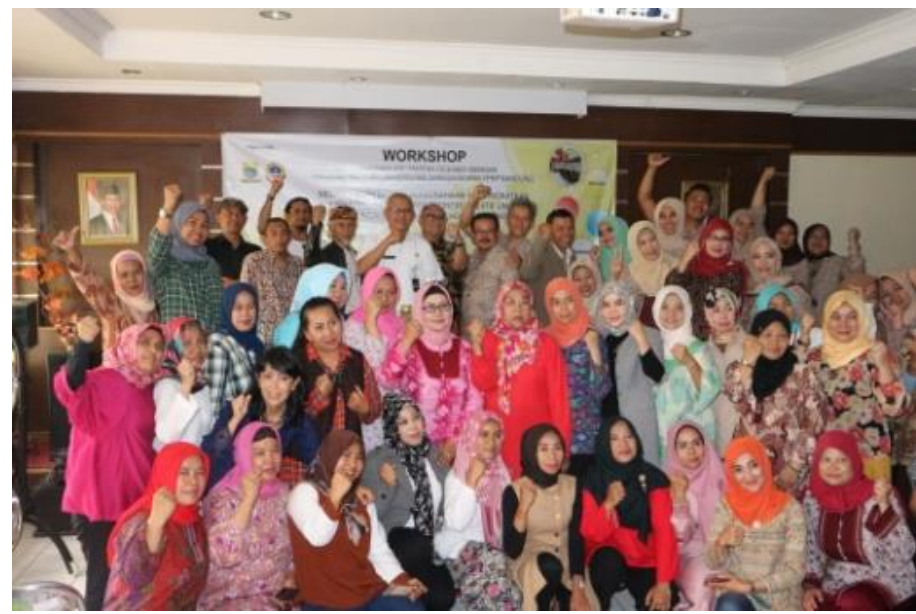

Gambar 3: Para UMKM Batik Nyere

\section{Hasil Evaluasi Pelatihan}

Respon dari hasil pelatihan dan workshop ini sangat baik, terlihat dari hasil evaluasi berupa kuisener dengan skala 5 dari tidak sesuai / tidak setuju hingga sangat setuju / sangat sesuai , memberikan hasil sebagai berikut :

1. Dari hasil pertanyaan pertanyaan apakah materi pelatihan sesuai dengan kebutuhan untuk pengembangan usaha dimasa datang, dominasi jawaban adalah pada setuju sekali (44\%) dan setuju (50\%).
2. Untuk pertanyaan apakah alokasi waktu untuk masing-masing materi pelatihan sudah sesuai, dominasi jawaban adalah sangat memadai $(44 \%)$, memadai $(34 \%)$ dan cukup memadai (22\%).

3. Untuk pertanyaan apakah bagaimana penyampaian untuk masing-masing materi oleh pemateri, dominasi jawaban adalah pada sangat menarik (44\%) dan menarik (37\%). 
4. Untuk pertanyaan apakah pelatihan untuk masing-masing materi perlu ditindaklanjuti, dominasi jawaban adalah setuju sekali (91\%).

\section{KESIMPULAN DAN SARAN}

\section{Kesimpulan}

Hasil dari kunjungan dan pelaksanaan Pengabdian Pada Masyarakat pada Batik nyere kecamatan Cicendo, belumlah memberikan hasil seperti yang diharapkan karena adanya keterbatasan waktu, sehingga interaksi dan informasi belum maksimal untuk kedua belah pihak. Sebagaimana pula keinginan dari para perajin dan hasil diskusi ,maka direncanakan akan ada tindak lanjut dari kegiatan PPM, antara lain :

1. Tindak lanjut pemahaman dengan menggunakan lembar kerja atau praktek dikarnakan kemarin keterbatasan waktu dari setiap materi yang diberikan.

2. Kunjungan industri ke batik yang lebih besar.

3. Belum adanya kesiapan mental untuk maju dan berkembang.

4. Tempat produksi masih terbatas.

5. Masih belum luasnya tempat untuk melakukan produksi
6. Belum adanya pembinaan yang berkelanjutan terhadap batik nyere.

7. Masih belum mampu melakukan atau mengerjakan laporan keuangan dengan baik.

8. Masih kurang tepatnya alokasi waktu untuk masing-masing pelatihan sehingga hasil belum optimal.

\section{Saran}

Beberapa saran terkait hasil pengabdian pada masyarakat :

1. Adanya workshop berkelanjutan bagi pengrajin batik nyere sehingga penerapan ilmu dan pengetahuan bagi pengrajin batik nyere lebih baik.

2. Adanya kunjungan untuk dapat melihat langsung bagaimana pembuatan produksi batik yang optimal.

\section{DAFTAR PUSTAKA}

[1] http://kemenperin.go.id/artikel/18193/ Bidik-Pasar-Jepang,-AS,-dan-Eropa,Nilai-Ekspor-Batik-Lampaui-USD-39Juta.

[2] https://fitinline.com/article/read/12langkah-mudah-membuat-batik-nyeredengan-sapu-lidi-yang-bisa-anda-coba

[3] Siswanto, M.Si (2005). Pengantar Manajemen. Edisi Pertama. Jakarta : PT. Bumi Aksara 